\title{
A Comprehensive Analysis of Interleukin-4 Receptor Polymorphisms and Their Association with Atopy and IgE Regulation in Childhood
}

\author{
Bernd Woitsch $^{\mathrm{a}}$ David Carr ${ }^{\mathrm{a}}$ Daniel Stachel ${ }^{\mathrm{b}} \quad$ Irene Schmida $^{\mathrm{a}}$ Stephan K. Weiland $^{\mathrm{c}}$ \\ Christian Fritzsch $^{d}$ Erika von Mutius ${ }^{a}$ Michael Kabesch ${ }^{a}$ \\ a University Children's Hospital Munich, Munich; bUniversity Children's Hospital Erlangen, Erlangen; \\ 'Department for Epidemiology, University of UIm, Ulm, and dUniversity Children's Hospital Leipzig, \\ Leipzig, Germany
}

\author{
Key Words \\ Atopy · Childhood · Immunoglobulin E · Interleukin-4 \\ receptor $\cdot$ Polymorphism $\cdot$ Single nucleotide \\ polymorphism
}

\begin{abstract}
Background: The interleukin (IL) 4/IL13 pathway is involved in the regulation of $\lg \mathrm{E}$ production associated with atopic diseases. Numerous polymorphisms have been identified in the coding region of the IL4 receptor $\alpha$ chain (IL4Ra) and previous association studies have shown conflicting results. Based on their putative functional role, polymorphisms A148G, T1432C and A1652G, located in the coding region of IL4Ra, were selected for association and haplotype studies in a large German population sample ( $n=1,120)$. Methods: Genotyping was performed using allele-specific PCR and restrictionenzyme-based assays. Haplotypes were estimated, and population-derived $\mathrm{IgE}$ percentiles $(50 \% \mathrm{lgE}>60 \mathrm{IU} / \mathrm{ml}$, $66 \% \mathrm{lgE}>115 \mathrm{lU} / \mathrm{ml}$ and $90 \% \mathrm{lgE}>457 \mathrm{IU} / \mathrm{ml}$ ) were calculated as outcome variables in a haplotype trend regression analysis. Results: In our population, only polymorphism T1432C showed a trend for a protective effect against atopic rhinitis (odds ratio, OR: 0.52, 95\% confidence interval, $\mathrm{Cl}: 0.26-1.02, \mathrm{p}=0.05)$. When haplotypes were calculated, one haplotype was significantly associ-
\end{abstract}

ated with elevated serum $\lg \mathrm{E}$ levels at the 50th percentile (OR 1.60, 95\% Cl 1.08-2.37, $\mathrm{p}=0.02$ ). Conclusions: These data indicate that IL4Ra polymorphisms, although suggested to be functionally relevant by in vitro studies, have only a minor influence on $\lg E$ regulation in our large population sample.

Copyright $@ 2004$ S. Karger AG, Basel

\section{Introduction}

The switching of immunoglobulin production from IgM to IgE in activated B lymphocytes is common to all atopic diseases. Two of the most important cytokines involved in IgE switching and the persistence of the allergic reaction are the pro-inflammatory molecules interleukin (IL) 4 and IL13. Both IL4 and IL13 affect the expression of IgE by signaling through a common pathway. Binding of IL4 and IL13 is facilitated through a heterodimeric surface receptor consisting of the IL4 receptor $\alpha$ chain (IL4Ra) and either the common $\gamma$ chain (for IL4 and IL13) or the $\alpha$ chain of the IL13 receptor (for IL13 only) [1-3]. On interaction with the receptor, intracellular signaling is initiated through the phosphorylation of signal transducer and activator of transcription 6 (STAT6) molecules which in turn penetrate the nucleus activating the transcription of target genes [4]. Located on chromo-

\begin{tabular}{ll}
\hline KARGER & ( ) 2004 S. Karger AG, Basel \\
Fax +4161306 1234 $34-2438 / 04 / 1354-0319 \$ 21.00 / 0$ \\
$\begin{array}{l}\text { E-Mail karger@karger.ch } \\
\text { www.karger.com }\end{array}$ & $\begin{array}{l}\text { Accessible online at: } \\
\text { www.karger.com/iaa }\end{array}$
\end{tabular}

Correspondence to: Dr. Michael Kabesch
Children's University Hospital, Ludwig Maximilians University Munich
Lindwurmstrasse 4, DE-80337 München (Germany)
Tel. +49 895160 2792, Fax +49 8951604764
E-Mail Michael.Kabesch@med.uni-muenchen.de 
some 16q12, ILRa has been associated initially with the hyper-IgE syndrome $[5,6]$, IgE regulation and the development of atopic diseases [7]. At least 14 polymorphisms have been described in the coding region of the gene, 10 of which lead to changes in the putative amino acid sequence [8]. However, association studies on the effect of single IL4Ra polymorphisms on IgE regulation and the development of atopic diseases have lead to conflicting results [9-13].

Thus, we genotyped a large German population sample $(\mathrm{n}=1,120)$ for three common single nucleotide polymorphisms (SNPs) located in the extracellular domain and two in the intracellular domain of the $\alpha$-chain of the receptor, spanning the whole IL4Ra gene. Haplotype analysis was performed to investigate interactions between polymorphisms within the IL4Ra gene.

\section{Methods}

The population used in this study has been described in detail previously [14-16]. Therefore, only methods pertaining to this analysis are given below. Informed written consent was obtained from all parents, and all study methods were approved by the ethics committees of the Bavarian Medical Council and the University of Leipzig.

\section{Subjects}

In this study, only children of German origin, 9-11 years of age, from Munich (southern Germany) and Leipzig (eastern Germany) who had both DNA and IgE data available were included in the analysis $(n=1,120$, Munich $n=528$, Leipzig $n=592)$. No significant differences between the study populations from both cities were found with respect to population characteristics [15]. The schools sent parental self-completion questionnaires on to the families. Children underwent skin prick testing, blood was collected for serum IgE measurements, and DNA extraction was performed from leukocytes. No selection bias was detected between those included and those who were not included in the study (data not shown).

\section{Questionnaire}

Children whose parents reported a doctor's diagnosis of either asthma, recurrent spastic or recurrent asthmatic bronchitis were classified as having asthma. Children were classified as having allergic rhinitis or atopic dermatitis when parents reported a doctor's diagnosis of hay fever or atopic eczema, respectively.

\section{Skin Prick Test}

In Munich and Leipzig, the sensitivity to six common aeroallergens (Dermatophagoides pteronyssinus, Dermatophagoides farinae, Alternaria tenuis, cat dander and mixed grass and tree pollens) was assessed using highly standardized extracts and lancets (ALK, Horsholm, Denmark). A child was considered atopic if a wheal reaction of more than $3 \mathrm{~mm}$ occurred to at least one specific allergen after subtraction of the negative control.

\section{Total Serum IgE Measurements}

Total serum IgE levels were measured using the Insulite system (DPC Biermann, Bad Nauheim, Germany). Based on the cross-sectional survey of children aged 9-11 years (International Study of Childhood Asthma and Allergy; $n=3,063$ ), IgE percentiles were calculated. For haplotype analysis, the 50th $(60.4 \mathrm{U} / \mathrm{ml}), 66$ th $(115 \mathrm{U} /$ $\mathrm{ml})$ and 90 th percentiles $(457 \mathrm{U} / \mathrm{ml})$ for total serum $\mathrm{IgE}$ were used as outcome variables. Percentiles were chosen for our haplotype analysis as they may better reflect the distribution of IgE levels in the population. As no differences in IgE levels were observed between subjects included/not included in the study or between populations from Leipzig and Munich (data not shown), percentiles may be assumed to be representative for a general German population aged 9-11 years where 50th, 66th and 90th percentiles correlate with modestly, moderately and highly elevated serum IgE levels.

\section{Molecular Genetic Methods}

Genomic DNA was extracted from whole blood by a standard salting out method [17]. All PCR reactions were carried out in a volume of $15 \mu \mathrm{l}$ containing $24 \mathrm{ng}$ of genomic DNA using standard thermocyclers (Eppendorf, Cologne, Germany). For initial genotyping, allele-specific PCR and standard sequencing were used to genotype the study population for three specific polymorphisms in the IL4 receptor gene. Specific primer and assay conditions used for genotyping are given in table 1 . The reproducibility of genotyping results was tested by restriction-endonuclease-based assays in at least $10 \%$ of random repeats. Hardy-Weinberg equations were calculated for all genotypes.

\section{Statistical Analysis}

Standard analysis of variance (ANOVA) for quantitative traits and $\chi^{2}$ tests for qualitative traits were used to compare means and proportions between groups. Total serum IgE levels were summarized descriptively with geometric means, and linear trends were tested in ANOVA models of log-transformed values. The haplotype trend regression model, where the estimated probabilities are modeled in a logistic regression for their association with a specific trait $[18,19]$, was used to calculate haplotype frequencies not directly observable in unrelated individuals. Two additional haplotyping methods were applied to confirm results, where the probabilities of each haplotype were dichotomized into binary variables using two predefined thresholds $(\operatorname{Pr}>0.80$ and $>0.0)$, followed by a $\chi^{2}$ test for association [20]. Only results consistent over all three haplotyping methods were reported. All haplotype analyses were carried out using SAS/Genetics, version 8.2 [19].

\section{Results}

The study population $(\mathrm{n}=1,120)$ was genotyped for the three putatively functional polymorphisms A148G, T1432C and A1652G in the IL4Ra gene. No selection bias was detected between those included and not included in the study (data not shown). Genotyping was successful in at least $95 \%$ of all samples: 1,092 samples for A148G, 1,074 for T1432C and 1,081 for A1652G. Allele frequencies were 0.57 for $\mathrm{A}$ at position $148,0.87$ for $\mathrm{T}$ at 
Table 1. Primers and assay conditions

\begin{tabular}{|c|c|c|c|}
\hline SNP & $\begin{array}{l}\text { Forward }\left(5^{\prime}\right) \text { primer } \\
\text { Reverse }\left(3^{\prime}\right) \text { primer }\end{array}$ & $\begin{array}{l}\text { Product } \\
\mathrm{bp}\end{array}$ & $\begin{array}{l}\text { Genotyping } \\
\text { assay }\end{array}$ \\
\hline IL4Ra A148G & $\begin{array}{l}\text { ACTCCGCCCTGCTCACC } \\
\text { TAGGCAGGTGTGAGGAGTATC }\end{array}$ & 409 & BcilV \\
\hline IL4Ra A148G & $\begin{array}{l}\text { GCC TCC GTT GTT CTC AGG TA } \\
\text { TGT GAG GAG CAT CCT TGG TÁ }\end{array}$ & 267 & RsaI \\
\hline IL4Ra A148G & $\begin{array}{l}\text { GCC TCC GTT GTT CTC AGG TAT } \\
\text { GCC TCC GTT GTT CTC AGG TAC } \\
\text { ATC CTT GGT GCA TGT GGT AAG } \\
\text { GCT TAT ACC CCT CTT CCC CAC } \\
\text { ACG CCC CTC GTC ATC GCA G }\end{array}$ & 257 & asPCR \\
\hline IL4Ra T1432C & $\begin{array}{l}\text { GAC ACG GTG ACT GGC TCG AGG } \\
\text { GCA TCG CCT GAG AGC AGC AG }\end{array}$ & 373 & BseRI \\
\hline IL4Ra T1432C & $\begin{array}{l}\text { GCT CTC TGG GAC ACG GTG ACT GGC TCT CGG } \\
\text { ATG GGG GAG TCA TGC CTT CTT } \bar{C} \text { CA CC } \underline{\text { TC }} \text { TCG G }\end{array}$ & 259 & $A v a \mathrm{I}$ \\
\hline IL4Ra A1652G & $\begin{array}{l}\text { GCT TAT ACC CCT CTT CCC CAC } \\
\text { ACG CCC CTC GTC ATC GCA G } \\
\text { CAC CGC ATG TAC AAA CTC CC } \\
\text { CCC CCA CCA GTG GCT ATC A }\end{array}$ & $\begin{array}{l}439 \\
288 \\
189\end{array}$ & $\begin{array}{l}\text { asPCR } \\
\text { asPCR } \\
\text { asPCR } \\
\text { asPCR }\end{array}$ \\
\hline IL4Ra A1652G & 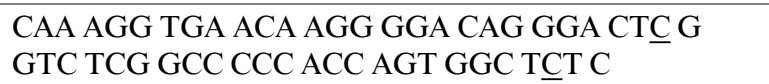 & 265 & $A v a \mathrm{I}$ \\
\hline
\end{tabular}

asPCR = Allele-specific PCR. Underlined bases represent mismatches introduced for restriction-enzyme-based digestions.

Table 2. IL $4 \mathrm{Ra}$ haplotypes based on the polymorphisms A148G, A1652G and T1432C and haplotype frequencies (haplotypes with frequencies $<3 \%$ were not considered)

\begin{tabular}{lll}
\hline No. & Haplotypes & Frequencies \\
\hline 1 & A-A-T & 0.47 \\
2 & A-G-C & 0.05 \\
3 & A-G-T & 0.05 \\
4 & G-A-T & 0.31 \\
5 & G-G-C & 0.07 \\
6 & G-G-T & 0.04 \\
\hline
\end{tabular}

position 1432 and 0.80 for $A$ at position 1652, respectively. No significant deviation from the Hardy-Weinberg equilibrium was observed with any polymorphism. Using a correlation coefficient $(\Delta)$, the linkage disequilibrium between the three SNPs was assessed to be low to moderate between all three SNPs $(\Delta=0.11$ for A148G and both other polymorphisms and $\Delta=0.66$ for $\mathrm{T} 1432 \mathrm{C}$ vs.
A1652G. Allele frequencies for the genotyped IL4Ra polymorphisms were similar to previously reported frequencies in Europeans, but differed from those reported in non-Caucasian populations $[8,20-23]$.

To assess the role of IL4 receptor polymorphisms in the development of asthma and atopy, association studies were performed, and the main atopic phenotypes of asthma, atopic rhinitis, atopic dermatitis, atopy by skin prick test and serum IgE were assessed. Only polymorphism T1432C showed a trend for a protective effect against the development of atopic rhinitis (T1432C: $0.52,95 \%$ confidence interval, CI: 0.26-1.02, $\mathrm{p}=0.05$ ). Furthermore, for A148G a borderline significant trend towards elevated serum $\mathrm{IgE}$ levels was observed: geometric means for serum IgE $(\mathrm{IU} / \mathrm{ml})$ were 47.1 in individuals with the wildtype allele versus 55.5 in carriers of the $G$ allele $(p=0.08)$, respectively.

Next we performed a haplotype analysis comprising the three polymorphisms A148G, A1652G and T1432C. When haplotypes were estimated using the ER method in the 1,043 samples for which complete genotyping information was available, only six of eight possible haplotypes 
Fig. 1. ORs and $95 \%$ CIs for IgE percentiles (50th, 66th and 90th percentiles) by IL4Ra haplotypes GAT and AAT(calculated using the haplotype trend regression model).

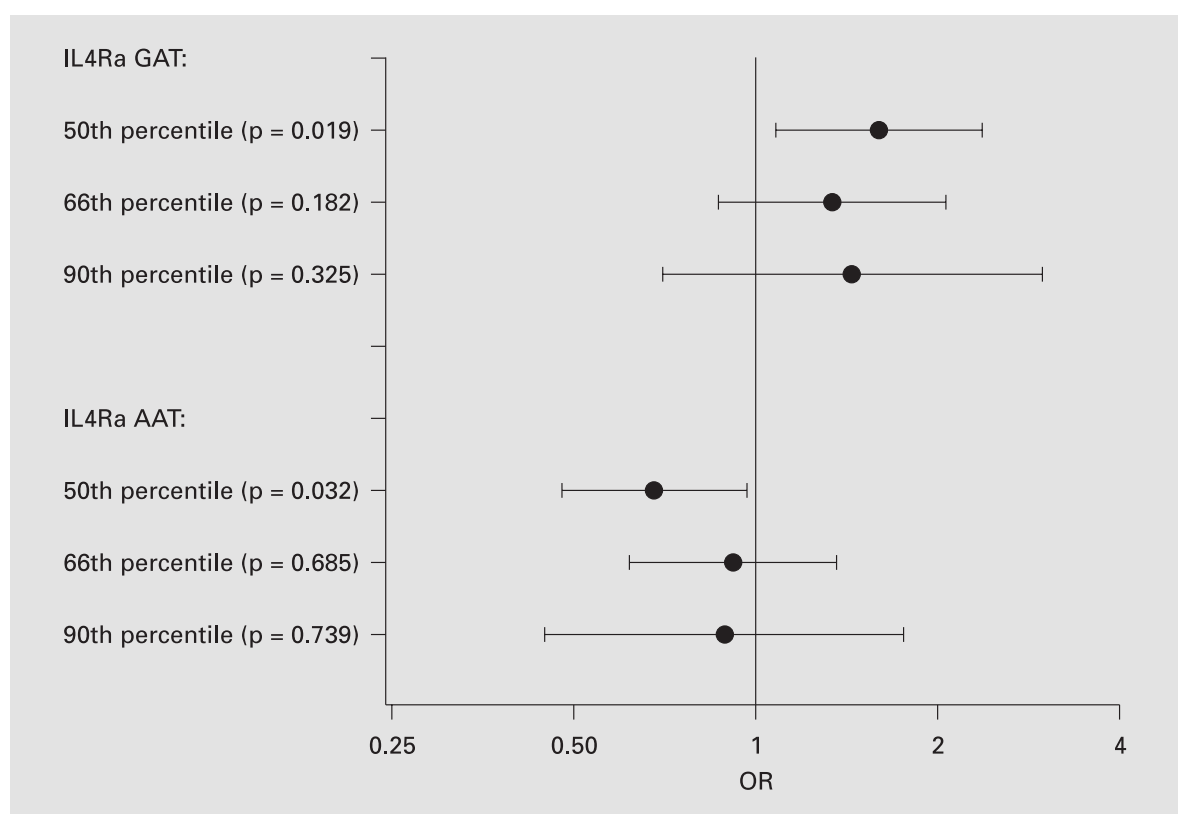

exceeded a frequency of $3 \%$ (table 2). For the haplotype analysis, percentiles for serum IgE levels based on our cross-sectional study in a German population were calculated instead of the widely used arbitrary cutoff point for elevated serum IgE levels of $100 \mathrm{IU} / \mathrm{ml}$. As shown in figure 1 , we observed a risk haplotype G-A-T with odds ratios of $1.60(95 \%$ CI 1.08-2.37, p = 0.02), for serum IgE levels above the 50th percentile, while the risk for elevated $\mathrm{IgE}$ at the 66th and 90th percentiles was not increased significantly. In contrast, the haplotypic combination A-A-T showed a protective effect against the development of elevated IgE levels with odds ratios of 0.68 (95\% CI 0.48-0.97, $\mathrm{p}=0.03$ ) for serum IgE above the 50th percentile. No associations between haplotypes and asthma, atopic diseases or atopy were observed (data not shown). All other haplotype combinations were too infrequent to perform adequate haplotype analysis (data not shown).

\section{Discussion}

The three polymorphisms tested in our population sample lead to putative amino acid changes. A148G leads to an amino acid change at position 50 of the extracellular domain of the receptor chain (Ile50Val). In vitro studies have shown increased IL4-dependent signaling and elevated IgE production in the presence of the A (Ile) allele [24]. In our study however, these findings were not con- firmed in our large study cohort. In contrast, carriers of the A allele showed a trend towards lower levels of serum IgE. Results from Japanese [24, 25] and European studies [23] were also conflicting. In summary, these results indicate that A148G may have only minor effects (if any) on the regulation of serum IgE levels or the development of atopic phenotypes.

Polymorphisms T1432C and A1652G lead to amino acid changes in Ser478Pro and Gln551Arg, respectively, in the intracellular domain of the IL4Ra chain. Thus, both polymorphisms have been suspected to influence the intracellular activation of the signaling cascade. As polymorphism A1652G is located one base pair from a STAT6-recruiting domain in IL4Ra, a functional relevance seemed possible. While Kruse et al. [1] showed an effect of the polymorphism on phosphorylation and signalling transduction, no such effect was observed in another functional study [26]. In association studies, conflicting results for both polymorphisms in different populations and ethnicities exist. While an association was initially observed in an inbred population of German ancestors (Hutterites) [20] and a study cohort from southern Germany [21], no such association was observed in our population sample or the German Multicenter Atopy Study [23].

To assess the effects of haplotypes in our cross-sectional study of unrelated subjects, haplotypes were estimated according to standard methods using the expectation maximization algorithm. Using this procedure, only weak 
Fig. 2. Comparative analysis of respective IL4Ra polymorphism effects on asthma. Respective allele frequencies were taken from previous reports, and ORs were calculated and evaluated graphically. Mitsuyasu et al. [24] studied asthma in adults and children.

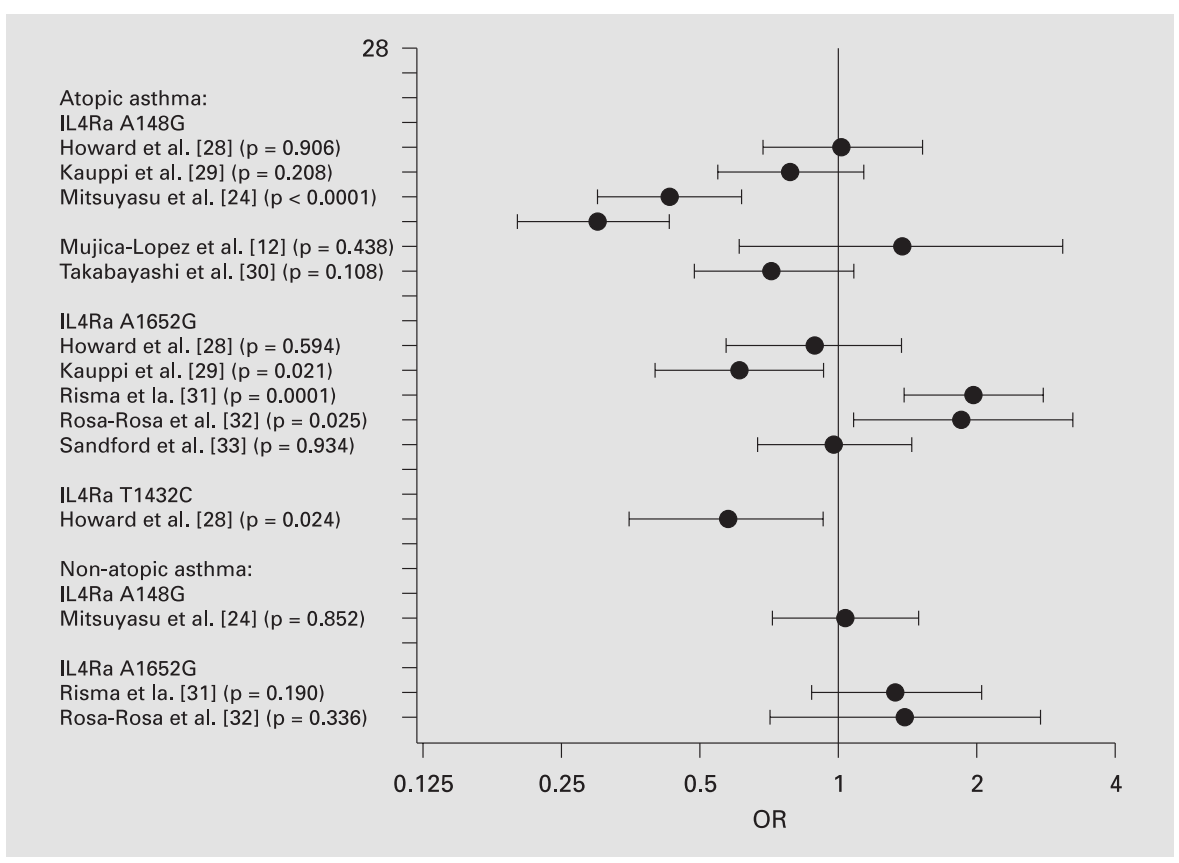

but significant associations between the regulation of serum IgE levels and IL4Ra haplotypes were detected. While the risk haplotype G-A-T conferred a risk for modestly elevated serum IgE levels (at the 50th percentile), the A-A-T haplotype was protective at the same level. As shown in figure 1 , the same trends for associations were observed for the 66th and 90th percentiles. However, as fewer observations contribute to these associations, the statistical significance decreased.

Only three out of 14 known polymorphisms in the IL4Ra-coding region were genotyped in our population and included in the haplotype analysis. However, it has been shown previously that other polymorphisms in the IL4Ra gene and the IL4R promoter were either very infrequent or in strong linkage disequilibrium with the polymorphisms genotyped here $[20,22,27]$. Thus, it seems unlikely that further, non-genotyped polymorphisms in the IL4Ra gene may confer significant effects on IgE regulation or the development of atopic diseases.

Even though a large body of literature exists on the putative effects of genetic variations in the IL4Ra gene on the development of atopic diseases and the regulation of serum IgE levels, it was not possible to perform a meta-analysis of the current literature. This was due to a lack of standardization between reports in terms of the phenotypes assessed, statistical methods and the presentation of the results of genotyping. In figure 2, results from association studies accessible for a comparative analysis of the effects of poly- morphisms A148G, T1432C and A1652G on asthma are summarized descriptively. As shown in this comparison, results vary greatly between different studies and populations. In our cross-sectional study, no significant association between IL4Ra polymorphisms and asthma was observed (fig. 2). However, small genetic effects requiring an even larger study population may have been missed.

In conclusion, our data suggest that IL4Ra polymorphisms exert only a minor effect on the regulation of serum IgE and do not contribute significantly to the development of atopic diseases in our large study cohort of German children. However, it cannot be excluded that IL4Ra polymorphisms interact with polymorphisms in other genes of the IL4/IL13 pathway or certain environmental factors that may have modifying effects on $\operatorname{IgE}$ regulation and the development of atopic diseases. While some aspects of these possible interactions, e.g. between IL13 and IL4Ra polymorphisms, have already been addressed [23,28], further studies on the complete pathway including IL4, IL13, IL4Ra and the intracellular signal transducer STAT6 may be necessary to elucidate the complex genetic regulation of serum IgE levels.

\section{Acknowledgments}

This work was founded by the German Ministry of Education and Research (BMBF) and National Genome Research Network research grants NGFN 01GS 0122 and NGFN IE-S08T03. 


\section{References}

1 Kruse S, Braun S, Deichmann K: Distinct signal transduction processes by IL-4 and IL-13 and influences from the Q551R variant of the human IL-4 receptor alpha chain. Respir Res 2002;3:24.

2 Shirakawa I, Deichmann KA, Izuhara I, Mao I, Adra CN, Hopkin JM: Atopy and asthma: Genetic variants of IL-4 and IL-13 signalling. Immunol Today 2000;21:60-64.

3 Idzerda R, March C, Mosley B, Lyman S Vanden Bos T, Gimpel S, et al: Human interleukin 4 receptor confers biological responsiveness and defines a novel receptor superfamily. $\mathrm{J}$ Exp Med 1990;171:861-873.

4 Kelly-Welch AE, Hanson EM, Boothby MR, Keegan AD: Interleukin-4 and interleukin-13 signaling connections maps. Science 2003;300: 1527-1528.

5 Pritchard MA, Baker E, Whitmore SA, Sutherland GR, Idzerda RL, Park LS, et al: The interleukin-4 receptor gene (IL4R) maps to $16 \mathrm{p} 11.2-16 \mathrm{p} 12.1$ in human and to the distal region of mouse chromosome 7 . Genomics 1991;10:801-806.

6 Hershey GK, Friedrich MF, Esswein LA, Thomas ML, Chatila TA: The association of atopy with a gain-of-function mutation in the alpha subunit of the interleukin-4 receptor (see comments). N Engl J Med 1997;337:1720-1725.

7 Hall I: Interleukin-4 receptor alpha gene variants and allergic disease. Respir Res 2000;1:68 .

8 Wu X, Di Rienzo A, Ober C: A population genetics study of single nucleotide polymorphisms in the interleukin 4 receptor alpha (IL4RA) gene. Genes Immun 2001;2:128-134.

9 Kimura K, Noguchi E, Shibasaki M, Arinami T, Yokouchi Y, Takeda K, et al: Linkage and association of atopic asthma to markers on chromosome 13 in the Japanese population. Hum Mol Genet 1999;8:1487-1490.

10 Noguchi E, Shibasaki M, Arinami T, Takeda K, Yokouchi Y, Kobayashi K, et al: No association between atopy/asthma and the Ile50val polymorphism of IL-4 receptor. Am J Respir Crit Care Med 1999;160:342-345.

11 Haagerup A, Bjerke T, Schiotz PO, Dahl R, Binderup HG, Kruse TA: No linkage and association of atopy to chromosome 16 including the interleukin-4 receptor gene. Allergy 2001; 56:775-779.

12 Mujica-Lopez KI, Flores-Martinez SE, RamosZepeda R, Castaneda-Ramos SA, Gazca-Aguilar A, Garcia-Perez J, Sanchez-Corona J: Association analysis of polymorphisms in the interleukin-4 receptor (alpha) gene with atopic asth$\mathrm{ma}$ in patients from western Mexico. Eur J Immunogenet 2002;29:375-378.
13 Tanaka K, Sugiura H, Uehara M, Hashimoto Y, Donnelly C, Montgomery DS: Lack of association between atopic eczema and the genetic variants of interleukin- 4 and the interleukin-4 receptor chain gene: Heterogeneity of genetic backgrounds on immunoglobulin $\mathrm{E}$ production in atopic eczema patients. Clin Exp Allergy 2001;31:1522-1527.

14 Weiland SK, von Mutius E, Hirsch T, Duhme $\mathrm{H}$, Fritzsch C, Werner B, et al: Prevalence of respiratory and atopic disorders among children in the East and West of Germany five years after unification. Eur Respir J 1999:862870.

15 Kabesch M, Tzotcheva I, Carr D, Hofler C, Weiland SK, Fritzsch C, et al: A complete screening of the IL4 gene: Novel polymorphisms and their association with asthma and IgE in childhood. J Allergy Clin Immunol 2003; 112:893-898.

16 Graves PE, Kabesch M, Halonen M, Holberg CJ, Baldini M, Fritzsch C, et al: A cluster of seven tightly linked polymorphisms in the IL13 gene is associated with total serum IgE levels in three populations of white children. J Allergy Clin Immunol 2000;105:506-513.

17 Miller SA, Dykes DD, Poletsky HF: A simple salting out procedure for extracting DNA from human nucleated cells. Nucleic Acids Res 1988; 16:1215.

18 Zaykin DV, Westfall PH, Young SS, Karnoub MA, Wagner MJ, Ehm MG: Testing association of statistically inferred haplotypes with discrete and continuous traits in samples of unrelated individuals. Hum Hered 2002;53: 79-91.

19 SAS Institute: SAS II: SAS/Genetics ${ }^{\circledR}$ User's Guide. Cary, SAS Institute, 2002.

20 Ober C, Leavitt SA, Tsalenko A, Howard TD, Hoki DM, Daniel R, Newman DL, Wu X, Parry R, Lester LA, Solway J, Blumenthal M, King RA, Xu J, Meyers DA, Bleecker ER, Cox NJ: Variation in the interleukin 4-receptor alpha gene confers susceptibility to asthma and atopy in ethnically diverse populations. Am J Hum Genet 2000;66:517-526.

21 Kruse S, Japha T, Tedner M, Sparholt SH, Forster J, Kuehr J, et al: The polymorphisms S503P and Q576R in the interleukin-4 receptor alpha gene are associated with atopy and influence the signal transduction. Immunology 1999;96:365-371.

22 Hackstein H, Hofmann H, Bohnert A, Bein G: Definition of human interleukin-4 receptor alpha chain haplotypes and allelic association with atopy markers. Hum Immunol 1999;60: 1119-1127.

23 Liu X, Beaty TH, Deindl P, Huang S-K, Lau S, Sommerfeld C, et al: Associations between total serum IgE levels and the 6 potentially functional variants within the genes IL4, IL13, and IL4RA in German children: The German Multicenter Atopy Study. J Allergy Clin Immunol 2003; 112:382-388
24 Mitsuyasu H, Yanagihara Y, Mao XQ, Gao PS, Arinobu Y, Ihara K, et al: Cutting edge: Dominant effect of Ile 50Val variant of the human IL4 receptor alpha-chain in IgE synthesis. J Immunol 1999;162:1227-1231.

25 Noguchi E, Shibasaki M, Arinami T, Takeda K, Yokouchi Y, Kobayashi K, Imoto N, Nakahara S, Matsui A, Hamaguchi H: Lack of association of atopy/asthma and the interleukin-4 receptor gene in Japanese. Clin Exp Allergy 1999;29:228-233.

26 Wang HY, Shelburne CP, Zamorano J, Kelly AE, Ryan JJ, Keegan AD: Cutting edge: Effects of an allergy-associated mutation in the human IL-4R alpha (Q576R) on human IL-4-induced signal transduction. J Immunol 1999;162: 4385-4389

27 Hackstein H, Hecker M, Kruse S, Bohnert A, Ober C, Deichmann KA, Bein G: A novel polymorphism in the $5^{\prime}$ promoter region of the human interleukin-4 receptor $\alpha$-chain gene is associated with decreased soluble interleukin-4 receptor protein levels. Immunogenetics 2001; 53:264-269.

28 Howard TD, Koppelman GH, Xu J, Zheng SL Postma DS, Meyers DA, et al: Gene-gene interaction in asthma: IL4RA and IL13 in a Dutch population with asthma. Am J Hum Genet 2002;70:230-236.

29 Kauppi P, Lindblad-Toh K, Sevon P, Toivonen HT, Rioux JD, Villapakkam A, Laitinen LA, Hudson TJ, Kere J, Laitinen T: A secondgeneration association study of the $5 \mathrm{q} 31$ cytokine gene cluster and the interleukin-4 receptor in asthma. Genomics 2001;77:35-42.

30 Takabayashi A, Ihara K, Sasaki Y, Suzuki Y, Nishima S, Izuhara K, Hamasaki N, Hara T: Childhood atopic asthma: positive association with a polymorphism of IL-4 receptor alpha gene but not with that of IL-4 promoter or Fc epsilon receptor I beta gene. Exp Clin Immunogenet 2000;17:63-70.

31 Risma KA, Wang N, Andrews RP, Cunningham CM, Ericksen MB, Bernstein JA, Chakraborty R, Hershey GK: V75R576 IL-4 receptor alpha is associated with allergic asthma and enhanced IL-4 receptor function. J Immunol 2002;169:1604-1610.

32 Rosa-Rosa L, Zimmermann N, Bernstein JA, Rothenberg ME, Khurana Hershey GK: The R576 IL-4 receptor alpha allele correlates with asthma severity. J Allergy Clin Immunol 1999;104:1008-1014.

33 Sandford AJ, Chagani T, Zhu S, Weir TD, Bai TR, Spinelli JJ, Fitzgerald JM, Behbehani NA, Tan WC, Pare PD: Polymorphisms in the IL4, IL4RA, and FCERIB genes and asthma severity. J Allergy Clin Immunol 2000;106:135-140. 